\title{
Integrating Conventional and Participatory Breeding Approaches in Assessment of Common Bean Varieties for Farmer Preffered Traits
}

\author{
Papias H. Binagwa ${ }^{1}$, Magdalena William ${ }^{2}$, Julius P. Mbiu ${ }^{2}$, Eunice Zakayo ${ }^{1}$, Shida M. Nestory ${ }^{1}$, Alex Kisamo ${ }^{1}$, \\ Mary Ndimbo ${ }^{3} \&$ Jean Claude Rubyogo ${ }^{4}$ \\ ${ }^{1}$ Tanzania Agricultural Research Institute-Selian, Arusha, Tanzania \\ ${ }^{2}$ Tanzania Agricultural Research Institute-Maruku, Bukoba, Tanzania \\ ${ }^{3}$ Tanzania Agricultural Research Institute-Uyole, Mbeya, Tanzania \\ ${ }^{4}$ International Centre for Tropical Agriculture, Arusha, Tanzania \\ Correspondence: Papias H. Binagwa, Tanzania Agricultural Research Institute-Selian, P.O. Box 6024, Arusha, \\ Tanzania. Tel: 255-764-951596. E-mail: papias.binagwa@tari.go.tz
}

Received: June 25, $2018 \quad$ Accepted: February 14, $2019 \quad$ Online Published: April 15, 2019

doi:10.5539/jas.v11n5p104 URL: https://doi.org/10.5539/jas.v11n5p104

\begin{abstract}
It is estimated that over $75 \%$ of rural households in Tanzania depend on common bean (Phaseolus vulgaris L.) for daily subsistence. Recently, farmers have been increasingly looking for improved bean varieties which meet specific market demands characterized with yellow seed colour, early maturing and/or adapted to local agro-ecologies. Study focused on assessing the performance of bean varieties for agronomic traits through variety and environmental interactions by identifying high yielding, ealy maturing and market demand seed classes among the tested materials. For testing adaptability and stability, experiments were conducted in low to high altitudes for two consecutive years using randomized complete block design (RCBD) with three replicates. Eight common bean varieties KG98, Navy line 1, KATB9, SABRYT, KATB1, Lyamungu 85, JESCA and Calima Uyole were used. Absolute, matrix and pairwise ranking were used integratively for farmers' and researcher's assessment and selection. Participatory variety selection approach gave farmers an opportunity to assess and select varieties from a range of near finished materials in the breeding process. As part of the Farmers' participatory variety selection process, seventeen participants as among the consumers $46 \%$ being women were selected to participate in a focused group discussion. Results revealed that, days to flowering, days to maturity and yield across the tested environments showed significant differences $(p \leq 0.05)$ as well as yield and diseases interactions for genotype, environment and season. Field data and farmers' assessment data showed two varieties of KATB1 (yellow round) and KATB9 (red round) for better performance (high yield) and grain preference respectively. It showed that, early maturing; seed type and marketability varieties are highly demanded by bean farmers in Tanzania.
\end{abstract}

Keywords: marketability, participatory, variety, early maturing, seed type

\section{Introduction}

Common bean (Phaseolus vulgaris) plays a principal role in the livelihoods of smallholder farmers in Tanzania as food security crop and source of income. It is the leading leguminous crop, accounting for $78 \%$ of land under legume cultivation (FAO, 2013). It is estimated that over $75 \%$ of rural households in Tanzania depend on common beans for daily subsistence (Kalyebara et al., 2008). Common bean production and national demand have been increasing while the average annual production of 790,818 MT for 2010 to 2014 is still low but the production appears relatively high compared to other sub-Saharan Africa but the actual yield per unit area is still low equated to the potential yield of $2 \mathrm{t} \mathrm{ha}^{-1}$ (FAOSTAT, 2014; Binagwa, 2016). In East African region, disease is the second biggest constraint to common bean production after low soil fertility (CIAT, 2003; PABRA, 2009). Fungal foliar diseases such as angular leaf spot (ALS) (Phaeoisariopsis griseola), anthracnose (Colletotrichum lindemuthianum); viral diseases bean common mosaic and necrotic virus (BCMNV); and bacterial diseases particularly common bacterial blight (CBB) (Xanthomonas axonopodis pv. phaseoli) and halo blight causes severe yield losses in common beans where they are prevalent and environmental conditions are favorable (Buruchara et al., 2010) and abiotic constraints but not limted to low soil fertility and drought (Wortmann \& 
Allen, 1994; Katungi et al., 2009). Economic diseases for Tanzania are ALS and CBB basing on occuurrance and distributions.

Recently, farmers have been increasingly looking for improved bean varieties characterized with early maturing, round seed type, diseases tolerant/resistant, market seed classes and/or varieties which are adapted to local agro-ecologies (Nile Basin, 2012). To ensure preferences and acceptance of developed common bean varieties, farmers are involved in variety selection procedures through participatory research approach. This involvement of farmers confirms awareness, acceptance, adoption and spatial diffusion of the developed common bean varieties (Letaa et al., 2015). The participatory variety selection refers to the approach that involve the examination of farmers' crops around harvest time, and the pre-selection of varieties by farmers from trials of many entries grown on a research station or on a farm (Witcombe et al., n.d.). This approach gives farmers an opportunity to assess and select varieties from a range of near finished materials in the breeding process and gives researchers the chance to understand the criteria farmers used in the selection process and identify farmer and market preferences (Witcombe et al., 1996). The participatory common bean breeding program is diverse in scope and have been further classified as contractual, consultative, collaborative, and collegiate with increasing degree of farmers involvement in the decision-making process (Bishaw \& Turner, 2008). Farmers are involved after various on-farm evaluations that assist in trait assessment for variety selection, assessment of genetic variability to identify desirable traits or eliminate undesirable traits during materials evaluation and confident incorporation of genetic tools such as marker-assisted breeding and bioinformatics (Sankaran et al., 2015). This happened because it is stated that the rigid release requirements and unrepresentative testing conditions can lead to mismatches between what is offered by crop researchers and what is desired by farmers (Witcombe \& Virk, 1997). This means there should be clear traits, gaps or challenges that are faced by farmers which should be addressed by plant breeders. The most preferred specific grait traits by farmers, traders and consumers at large include round medium sized seeds for better market class, early maturing, drought tolerant, diseases tolerant/resistant and high. It has showed that the improved bean varieties in East Africa is the best-known example of the successful application of PVS which has fueled common bean crop improvement in several countries including Rwanda, Tanzania, and Malawi (Weltzien et al., 2003).

Smallholder farmers have limited access to pesticides and fertilizer and are suffering most from this production loss, this study focused on evaluating bean varieties in different agro-ecologies in Tanzania and involved farmers during selection. This is the breeding approaches which is most ecological and economical mean to control diseases in low input agriculture, and particularly important to maintain stable yields of smallholder farming systems. The objective was to assess the effects of integrate conventional and participatory breeding approaches in assessment of common bean varieties for farmer preffered traits by i) identifying early maturing, diseases tolerant/resistant and high yielding varieties ii) identify market seed classes that preferred by local farmers, consumers and traders.

\section{Materials and Methods}

Total of eight bean varieties including checks (KG98, Navy line 1, KATB9, SABRYT, KATB1 sourced from CIAT and KARLO Kenya) and Lyamungu 85, JESCA and calima Uyole were evaluated on-farm across different agro-ecologies that representing common bean growing areas in the country for adaptability and stability studies. Varieties were tested at Selian-Arusha (1,414 m. a.s.1.), Uyole Mbeya (2,014 m. a.s.l.), Maruku-Kagera (1,352 m. a.s.l.) and Lambo-Kilimanjaro (995 m. a.s.l.) locations in 2014 to 2016 long rain growing season(s) while the Participatory Variety Selection conducted at Karatu, Babati and Bukoba districts. In all locations the trials were laid out for different years in Randomized Complete Block Design (RCBD) with 3 replications. The experimental plot size was 4 rows, $5 \mathrm{~m}$ long and $50 \mathrm{~cm}$ apart and $20 \mathrm{~cm}$ within a row. The net plot size was 4.2 $\mathrm{m}^{2}$ across testing sites. Observations and data collection were made on days to $50 \%$ flowering, diseases severity 1-9 scale, 1 = non-pathogenic, 9 = pathogenic (CIAT, 1987) and days to maturity. The grain yield was measured from the centered two rows using precised balanced scale $(0.01 \mathrm{~g})$ when grains were at $14 \%$ moisture content. The collected and organized data were analyzed using GenStat 16th Edition with the following linear model Yijk $=\mu+\mathrm{Gi}+\gamma \mathrm{j}+\mathrm{Gi} \cdot \gamma \mathrm{j}+2 \mathrm{k}+\mathrm{Gi} \cdot \gamma \mathrm{j} \cdot 2 \mathrm{k}+\mathrm{eijk}$, where; Yijk $=$ Response variable (Yield) with variety $\mathrm{i}$, environment $\mathrm{j}$ and season $\mathrm{k} ; \mu=$ Overall mean for all the observed response; $\mathrm{Gi}=$ Fixed effect of variety; $\gamma \mathrm{j}=$ random environmental effect of the observed response; Gi $\gamma \mathrm{j}=$ Interaction effects between variety and environment; $2 \mathrm{k}=$ Random effect of relication within a season; Gi $\cdot \gamma \mathrm{j} \cdot 2 \mathrm{k}=$ Interaction effect of variety, environment and season; eijk $=$ Random term error which is assumed to be normally distributed with 0 mean and variance $\delta^{2}$ which were summarized in a given results.

Farmers' assessments were conducted during physiological maturity of common bean varieties so that farmers could observe clearly early mauring, diseases tolerant/resistant and yield paramers (pods per plant and seeds per 
pod). In the on-station testing, farmers were engaged to set the selection as; early maturity, drought tolerance, high yielding and market preference. The most common criteria used for assessing drought was observing around margins of leaves with the dead leaf tissue between veins toward the midrib, folding of leaves and signs of early maturing (Texas A\&M Agrilife Extention Book (n.d.)). To assess seed market class preferences and grain quality, seeds from previous season were placed along each plot for observation and assessment. Other farmer assessment methodology for different traits were adopted with amendments of the one used by Kund et al (2015a, 2015b) on pigeon pea (Cajanus cajan L.). Total of 17 participants $46 \%$ being women as represantive of farmers and consumers were selected according to the standard number of participants required for Focus Group Discussion (FGD) (Stewart et al., 2007; Gibbs, 1997) in crop assessment. The farmers who participated had either tested by themselves the varieties or had direct exposure to them through the on-farm trials, and with long time experience in bean farming this was done through volunteering sampling. The varieties were evaluated using absolute, pair wise and matrix ranking assessment tool as the researchers mentioned criteria required and farmers ranked them according to their prioritization. The gender disintegration was highlighted as different groups of men and women were assembled and segregated in groups for the assessment of their preferences. In common bean systems, market traits refer to consumer preferences for bean characteristics along the bean value chains. For example, in different countries consumers prefers different market classes; red mottled for Uganda, Tanzania, Ethiopia, Malawi and Zambia; large red kidneys for USA and Belgium, round yellow for Kenya, Tanzania and Burundi. All these preferences are accompanied with other characteristics of canning quality, color, shape, size and other cooking properties such as cooking time and digestibility (Mishili et al., 2009).

\section{Results and Discussion}

The targeted traits for measuring the varieties preferences and productvity were early maturing, diseases tolerant/resistant, seed yield stability and market demand. There was significant difference $(p \leq 0.05)$ on days to flowering (Table 1), days to maturity (Table 2) and yield across four different environments and seasons with exception to Lambo Kilimanjaro where yield $\left(\mathrm{kg} \mathrm{ha}^{-1}\right)$ resulted not significant in 2014/15 season (Table 5a). This insignificant may be because of the high incidence of variety being tested in different envornment which complicates the testing picture in cropping systems cultivated in marginal environments (Ceccarelli et al., 1996). Based on the results, proposed bean candidates KATB1 and KATB9 showed less number for days to flowering (Table 1) and full maturity (Table 2) compared to standard released bean varieties JESCA and Lyamungu 85 as well as market grain quality for KATB 1 (Tables 6, 7,8 and 9). Other studies states that the production environment is not only marginal but also heterogeneous, this statement was revealed by barley breeders do the bulk of their selection in farmers' fields in spatially disperse locations (Ceccarelli et al., 2004). Severity of ALS and CBB was high in 2014/15 season than the rest season and results shows that KG98 was highly susceptible with a score of $>6.00$ across the tested environments (Tables 3 and 4 ).

Despite to this merit, the yield of these proposed bean varieties was above $1 \mathrm{t} \mathrm{ha}{ }^{-1}$ across $87.5 \%$ of testing locations with exception to Lambo in 2014/15 which shows less yield even in other varieties, probably was because of erratic drought. In neigbouring countries (Kenya and Burundi) where these varieties released the yield ranged from 1,123-1,197 $\mathrm{kg} \mathrm{ha}^{-1}$ while for Tanzania the seed yield ranged 1,050-2,658 $\mathrm{kg} \mathrm{ha}^{-1}$ (Table 5a). This difference was due to erratic rainfall (drought) in the testing locations. Generally, both on farm and on station trials showed better adaptability and stability at both high and mid altitudes like what happened to advanced yield trials conducted in other neigbouring countries. The KATB1 flowered (31-32 days after planting) and matured (75-79 days after planting) below the mean value of the location while the check variety Lyamungu 85 and Calima Uyole had higher number of days to flowering and maturity compared to the mean yield of the location (Tables 1 and 2). This explains the need to release these varieties due to their advantage in early maturity compared to the released varieties which means they have characteristics of escaping drought condition. 
Table 1. Days to flowering of common bean varieties across seasons and environments

\begin{tabular}{|c|c|c|c|c|c|c|c|c|}
\hline \multirow{3}{*}{ Varieties } & \multicolumn{8}{|c|}{ Experimental locations } \\
\hline & \multicolumn{2}{|c|}{ Selian } & \multicolumn{2}{|c|}{ Uyole } & \multicolumn{2}{|c|}{ Lambo } & \multicolumn{2}{|c|}{ Maruku } \\
\hline & $2014 / 15$ & $2015 / 16$ & $2014 / 15$ & $2015 / 16$ & $2014 / 15$ & $2015 / 16$ & $2014 / 15$ & $2015 / 16$ \\
\hline KATB1 & 32.00 & 32.00 & 31.00 & 31.00 & 32.00 & 32.00 & 32.00 & 31.00 \\
\hline KATB9 & 32.00 & 32.00 & 32.00 & 33.00 & 32.00 & 32.00 & 32.00 & 33.00 \\
\hline JESCA & 33.00 & 33.00 & 32.00 & 34.00 & 32.00 & 35.00 & 35.00 & 36.00 \\
\hline Calima Uyole & 34.00 & 34.00 & 36.33 & 36.33 & 36.33 & 34.00 & 36.00 & 36.00 \\
\hline Navy line 1 & 36.00 & 36.00 & 35.65 & 35.65 & 35.65 & 36.00 & 36.00 & 36.00 \\
\hline SARBYT & 36.00 & 36.00 & 37.00 & 37.00 & 37.10 & 36.00 & 35.33 & 35.33 \\
\hline Lyamungu 85 & 36.00 & 36.00 & 37.67 & 36.67 & 37.67 & 36.00 & 36.00 & 36.00 \\
\hline KG98 & 42.00 & 42.00 & 42.33 & 42.33 & 42.33 & 42.00 & 41.33 & 41.33 \\
\hline Mean & 35.00 & 35.12 & 35.42 & 35.42 & 35.42 & 35.13 & 35.58 & 35.58 \\
\hline CV\% & 0.90 & 0.90 & 2.10 & 2.10 & 2.10 & 0.90 & 4.30 & 4.30 \\
\hline LSD & 0.54 & 0.50 & 1.30 & 1.30 & 1.30 & 0.54 & 2.65 & 2.65 \\
\hline $\mathrm{P}=0.05$ & $*$ & $*$ & $*$ & $*$ & $*$ & $*$ & $*$ & $*$ \\
\hline
\end{tabular}

Note. ${ }^{*}=$ significant.

Table 2. Days to full maturity of varieties across seasons and envornment

\begin{tabular}{|c|c|c|c|c|c|c|c|c|}
\hline \multirow{3}{*}{ Varieties } & \multicolumn{8}{|c|}{ Experimental locations } \\
\hline & \multicolumn{2}{|c|}{ Selian } & \multicolumn{2}{|c|}{ Uyole } & \multicolumn{2}{|c|}{ Lambo } & \multicolumn{2}{|c|}{ Maruku } \\
\hline & $2014 / 15$ & $2015 / 16$ & $2014 / 15$ & $2015 / 16$ & $2014 / 15$ & $2015 / 16$ & $2014 / 15$ & $2015 / 16$ \\
\hline KATB1 & 75.00 & 75.00 & 76.00 & 76.00 & 78.00 & 76.00 & 76.00 & 79.00 \\
\hline KATB9 & 77.00 & 77.00 & 78.00 & 79.00 & 79.00 & 80.00 & 76.00 & 80.00 \\
\hline JESCA & 79.00 & 79.00 & 80.00 & 80.00 & 81.00 & 82.00 & 79.00 & 81.00 \\
\hline Calima Uyole & 86.00 & 86.00 & 86.00 & 86.00 & 86.00 & 86.00 & 86.00 & 86.00 \\
\hline Navy line 1 & 88.00 & 88.00 & 88.00 & 88.00 & 88.00 & 88.00 & 88.99 & 88.99 \\
\hline SARBYT & 89.00 & 89.00 & 89.00 & 89.00 & 89.00 & 89.00 & 89.00 & 89.00 \\
\hline Lyamungu 85 & 87.00 & 87.00 & 87.00 & 87.00 & 87.00 & 87.00 & 87.00 & 87.00 \\
\hline KG98 & 89.00 & 89.00 & 89.00 & 89.00 & 89.00 & 89.00 & 89.00 & 89.00 \\
\hline Mean & 87.25 & 87.25 & 87.21 & 87.21 & 89.00 & 89.00 & 87.21 & 87.20 \\
\hline CV\% & 1.20 & 1.20 & 1.20 & 1.20 & 1.20 & 1.20 & 1.20 & 1.20 \\
\hline LSD & 1.81 & 1.81 & 1.88 & 1.88 & 1.81 & 1.81 & 1.88 & 1.88 \\
\hline $\mathrm{P}=0.05$ & $*$ & $*$ & $*$ & $*$ & $*$ & $*$ & $*$ & $*$ \\
\hline
\end{tabular}

Note. ${ }^{*}=$ significant.

Table 3. Diseases severity scores (1-9) across environment 2014/15

\begin{tabular}{|c|c|c|c|c|c|c|c|c|}
\hline \multirow{3}{*}{ Varieties } & \multicolumn{8}{|c|}{ Experimental locations } \\
\hline & \multicolumn{2}{|c|}{ Selian } & \multicolumn{2}{|c|}{ Uyole } & \multicolumn{2}{|c|}{ Lambo } & \multicolumn{2}{|c|}{ Maruku } \\
\hline & ALS & $\mathrm{CBB}$ & ALS & CBB & ALS & CBB & ALS & CBB \\
\hline KATB1 & 3.00 & 4.00 & 5.00 & 4.00 & 3.00 & 2.00 & 4.00 & 3.00 \\
\hline KATB9 & 3.00 & 4.00 & 3.00 & 4.00 & 3.00 & 1.00 & 5.00 & 1.00 \\
\hline JESCA & 4.00 & 4.00 & 4.00 & 3.00 & 3.00 & 2.00 & 4.00 & 2.00 \\
\hline Calima Uyole & 4.00 & 2.00 & 4.00 & 4.00 & 3.00 & 2.00 & 4.00 & 3.00 \\
\hline Navy line 1 & 2.00 & 2.00 & 3.00 & 2.00 & 4.00 & 1.00 & 5.00 & 1.00 \\
\hline SARBYT & 3.00 & 2.00 & 2.00 & 3.00 & 2.00 & 3.00 & 2.00 & 4.00 \\
\hline Lyamungu 85 & 2.00 & 1.00 & 3.00 & 2.00 & 3.00 & 1.00 & 2.00 & 1.00 \\
\hline KG98 & 7.00 & 2.00 & 6.00 & 2.00 & 6.00 & 2.00 & 6.00 & 1.00 \\
\hline Mean & 3.00 & 2.62 & 3.79 & 2.96 & 3.38 & 2.04 & 4.00 & 1.92 \\
\hline $\mathrm{CV} \%$ & 13.7 & 23.5 & 23.6 & 28.0 & 26.6 & 39.5 & 29.4 & 63.90 \\
\hline LSD & 0.81 & 1.08 & 1.57 & 1.45 & 1.57 & 1.41 & 2.06 & 2.15 \\
\hline $\mathrm{p}=0.05$ & $<0.001 *$ & $<0.001 *$ & $0.007 *$ & $\mathrm{~ns}$ & $0.004 *$ & ns & $0.010^{*}$ & ns \\
\hline
\end{tabular}

Note. ALS $=$ Angular Leaf Spot, $\mathrm{CBB}=$ Common Bacterial Blight, $\mathrm{ns}=$ not significant, $*$ = significant. 
Table 4. Diseases severity scores (1-9) across environment 2015/16

\begin{tabular}{|c|c|c|c|c|c|c|c|c|}
\hline \multirow{3}{*}{ Varieties } & \multicolumn{8}{|c|}{ Experimental locations } \\
\hline & \multicolumn{2}{|c|}{ Selian } & \multicolumn{2}{|l|}{ Uyole } & \multicolumn{2}{|l|}{ Lambo } & \multicolumn{2}{|c|}{ Maruku } \\
\hline & ALS & CBB & ALS & CBB & ALS & CBB & ALS & CBB \\
\hline KATB1 & 1.00 & 2.00 & 6.00 & 1.00 & 2.00 & 3.00 & 3.00 & 1.00 \\
\hline KATB9 & 4.00 & 3.00 & 5.00 & 2.00 & 2.00 & 3.00 & 3.00 & 1.00 \\
\hline JESCA & 4.00 & 2.00 & 6.00 & 1.00 & 2.00 & 5.00 & 3.00 & 2.00 \\
\hline Calima Uyole & 3.00 & 2.00 & 4.00 & 1.00 & 4.00 & 4.00 & 4.00 & 1.00 \\
\hline Navy line 1 & 4.00 & 2.00 & 5.00 & 2.00 & 3.00 & 4.00 & 3.00 & 1.00 \\
\hline SARBYT & 3.00 & 3.00 & 26.00 & 3.00 & 4.00 & 4.00 & 2.00 & 1.00 \\
\hline Lyamungu 85 & 3.00 & 3.00 & 4.00 & 2.00 & 3.00 & 5.00 & 2.00 & 1.00 \\
\hline KG98 & 4.00 & 3.00 & 4.00 & 1.00 & 5.00 & 5.00 & 5.00 & 1.00 \\
\hline Mean & 3.17 & 2.50 & 4.83 & 1.54 & 3.21 & 4.17 & 3.08 & 1.08 \\
\hline $\mathrm{CV} \%$ & 56.6 & 30.9 & 10.5 & 59.0 & 30.9 & 25.9 & 32.5 & 37.7 \\
\hline LSD & 3.14 & 1.35 & 0.89 & 1.56 & 1.75 & 1.89 & 1.76 & 0.71 \\
\hline $\mathrm{p}=0.05$ & $\mathrm{~ns}$ & ns & $<0.001 *$ & ns & $0.028 *$ & $\mathrm{~ns}$ & ns & ns \\
\hline
\end{tabular}

Note. $\mathrm{ALS}=$ Angular Leaf Spot, $\mathrm{CBB}=$ Common Bacterial Blight, $\mathrm{ns}=$ not significant, $*=$ significant.

Table 5a. Grain yield $\left(\mathrm{kg} \mathrm{ha}^{-1}\right)$ observed in varieties cultivated in several locations in Tanzania

\begin{tabular}{|c|c|c|c|c|c|c|c|c|}
\hline \multirow{3}{*}{ Varieties } & \multicolumn{8}{|c|}{ Experimental locations } \\
\hline & \multicolumn{2}{|c|}{ Selian } & \multicolumn{2}{|c|}{ Uyole } & \multicolumn{2}{|c|}{ Lambo } & \multicolumn{2}{|c|}{ Maruku } \\
\hline & $2014 / 15$ & $2015 / 16$ & $2014 / 15$ & $2015 / 16$ & $2014 / 15$ & $2015 / 16$ & $2014 / 15$ & $2015 / 16$ \\
\hline KATB1 & 1341.20 & 1222.00 & 1195.00 & 1920.00 & 1134.30 & 1345.00 & 1307.40 & 1087.40 \\
\hline КАТВ9 & 1359.84 & 1889.00 & 1879.00 & 2658.00 & 942.78 & 1881.00 & 1294.60 & 1050.50 \\
\hline JESCA & 1455.16 & 1897.00 & 1717.00 & 1863.00 & 965.24 & 1344.00 & 797.00 & 800.00 \\
\hline Calima Uyole & 1306.03 & 1152.00 & 1879.00 & 1333.00 & 1075.40 & 1423.00 & 599.50 & 629.80 \\
\hline Navy line 1 & 1058.25 & 1968.00 & 1059.00 & 2083.00 & 746.75 & 1172.00 & 484.20 & 697.60 \\
\hline SARBYT & 1367.94 & 2405.00 & 1023.00 & 2162.00 & 1395.87 & 916.00 & 1858.50 & 545.30 \\
\hline Lyamungu 85 & 1156.83 & 1040.00 & 1512.00 & 1400.00 & 676.51 & 1301.00 & 774.00 & 1024.20 \\
\hline KG98 & 1215.95 & 950.00 & 2526.00 & 896.00 & 1150.63 & 882.00 & 748.00 & 401.30 \\
\hline Mean & 1282.70 & 1502.00 & 1591.60 & 1789.30 & 1010.90 & 1283.00 & 983.00 & 779.50 \\
\hline $\mathrm{CV} \%$ & 16.40 & 3.10 & 29.30 & 19.10 & 37.20 & 20.60 & 20.80 & 19.00 \\
\hline LSD & 369.21 & 82.58 & 816.52 & 597.61 & 658.12 & 462.53 & 357.52 & 258.73 \\
\hline $\mathrm{p}=0.05$ & ns & $<0.001^{*}$ & $0.021^{*}$ & $<0.001^{*}$ & ns & $0.010^{*}$ & $<0.001 *$ & $<0.001 *$ \\
\hline
\end{tabular}

Note. $\mathrm{ns}=$ not significant, $*=$ significant.

Genotype, environment and season interactions was significantly different $(<.001)$ Table $5 \mathrm{~b}$ in terms of yield. The average highest yield was at Uyole $\left(1690.46 \mathrm{~kg} \mathrm{ha}^{-1}\right)$ followed with Selian $\left(1892 \mathrm{~kg} \mathrm{ha}^{-1}\right)$ then Lambo $\left(1446.98 \mathrm{~kg} \mathrm{ha}^{-1}\right)$ and last Maruku $\left(881.26 \mathrm{~kg} \mathrm{ha}^{-1}\right)$. Talking about these two seasons, the 2015/16 had ana average yield of $1338.69 \mathrm{~kg} \mathrm{ha}^{-1}$ while that of 2014/15 showed an average of $1217.05 \mathrm{~kg} \mathrm{ha}^{-1}$. Like wise, the interactions effects observed at foliar disaeses for each environment tested. 
Table $5 \mathrm{~b}$. Combined genotype, environment and season interactions

\begin{tabular}{|c|c|c|c|}
\hline Varieties & Environment & $2014 / 15\left(\mathrm{~kg} \mathrm{ha}^{-1}\right)$ & $2015 / 16\left(\mathrm{~kg} \mathrm{ha}^{-1}\right)$ \\
\hline \multirow[t]{4}{*}{ Calima uyole } & Lambo & 1075.40 & 1422.67 \\
\hline & Maruku & 599.51 & 1050.50 \\
\hline & Selian & 1306.03 & 1152.00 \\
\hline & Uyole & 1878.73 & 1333.33 \\
\hline \multirow[t]{4}{*}{ SABYT } & Lambo & 746.75 & 1172.00 \\
\hline & Maruku & 484.16 & 697.62 \\
\hline & Selian & 1058.25 & 1968.25 \\
\hline & Uyole & 1059.29 & 2082.54 \\
\hline \multirow[t]{4}{*}{ Navy line } & Lambo & 1395.87 & 916.07 \\
\hline & Maruku & 1858.45 & 545.28 \\
\hline & Selian & 1367.94 & 2404.76 \\
\hline & Uyole & 1022.7 & 2161.51 \\
\hline \multirow[t]{4}{*}{ Jesca } & Lambo & 965.24 & 1344.00 \\
\hline & Maruku & 797.03 & 800.00 \\
\hline & Selian & 1455.16 & 1396.83 \\
\hline & Uyole & 1717.22 & 1863.02 \\
\hline \multirow[t]{4}{*}{ KATB1 } & Lambo & 1134.29 & 1344.67 \\
\hline & Maruku & 1307.44 & 629.76 \\
\hline & Selian & 1341.19 & 1222.22 \\
\hline & Uyole & 1195.16 & 1920.48 \\
\hline \multirow[t]{4}{*}{ KATB9 } & Lambo & 942.78 & 1881.33 \\
\hline & Maruku & 1294.60 & 1024.21 \\
\hline & Selian & 1359.84 & 1888.89 \\
\hline & Uyole & 1821.59 & 2657.62 \\
\hline \multirow[t]{4}{*}{ KG98 } & Lambo & 1150.63 & 882.13 \\
\hline & Maruku & 748.20 & 401.27 \\
\hline & Selian & 1215.95 & 950.40 \\
\hline & Uyole & 2526.27 & 896.00 \\
\hline \multirow[t]{4}{*}{ Lyamungu 85} & Lambo & 676.51 & 1301.33 \\
\hline & Maruku & 774.71 & 1087.37 \\
\hline & Selian & 1156.83 & 1040.00 \\
\hline & Uyole & 1511.98 & 1400.00 \\
\hline
\end{tabular}

Note. $\mathrm{G} \cdot \mathrm{S}=$ genotype Season interactions, G.E $\cdot \mathrm{S}=$ Genotype, Environment and Season interactions.

$\mathrm{P}<0.001 ; \mathrm{CV} \%=26.60 ; \mathrm{LSD}$ of $\mathrm{G} \cdot \mathrm{S}=254.36$ and $\mathrm{G} \cdot \mathrm{E} \cdot \mathrm{S}=508.72$.

Market criteria was the most preferred followed by better yield and early maturity and the varieties that scored best in early maturity and market aspects were KATB1 and KATB9 compared to other varieties used (Tables 6 and 9). Similar study on early-maturing pearl millet variety Okashana 1 was another PVS success story in Sub-Saharan Africa (Bidinger, 1998) whereby ICRISAT-India generated variety then selected by farmers in Namibia in 1987 and released in 1989 as official variety and ready to be used by farmers in the country. In Absolute ranking KATB1 had the highest score followed by KATB9 and Lyamungu and Navy line 1 then SARBYT (Table 11) then more preferred by farmers; In Matrix ranking KATB1 had the highest scores whereas in pairwise ranking KATB1 scored higher than KATB9, Lyamungu 85 and JESCA. This shows that variety KATB1 was the most preferred since it was accepted in all tested sites with scoring of 5 points followed by KATB9, Lyamungu and JESCA (Tables 6, 7, 8, 9 and 10). It is not necessary that all tested materials should be preferred or released by the authority and that's why in eight varieties only two were accepted by farmers and released by seed authorities in the nation. Studies conducted by Tripp in 1997 for rice varieties, several varieties were tested in India but was not released because of perceived fatal flaw of susceptibility to lodging. Since the acceptance or rejection of any variety/technology is based on farmers' criteria which is assessed at the end of the season particularly during maturity stage. Therefore, farmer's data revealed that common bean varieties, KATB1 
and KATB9 were the most preferred in Tanzania. Similar convetional-farmer engagement integrative research approach was applied in Peru in the final evaluation and six of the most promising clones from six years of on-station selection and three years of testing in farmers' testing farmers selected seedling no. 380389.1. This selection was released nationally as Canchan-INIAA in 1990 (Gastelo et al., 1991). The most preferred criteria by farmers in the variety selection were good market quality and; high yield respectively. The varieties that scored excellent were KATB1, KATB 9, Navy line and checks for good market, high yielding and tolerance in pests/disease respectively. Also, the preferences were gendered whereby Lyamungu 85 and SABRYT were preferred cultivars/varieties by men than women (Table 4). The pair wise ranking results were similar to those found through absolute and matrix rankings for all tested varieties (Tables 6 and 7).

Table 7. Matrix ranking common bean varieties farmers' selection at Maruku-Kagera

\begin{tabular}{|c|c|c|c|c|c|c|c|c|c|}
\hline \multirow{2}{*}{ Criteria } & \multicolumn{7}{|c|}{ Common Bean varieties Releasing Candidates } & \multirow{2}{*}{ Total } & \multirow{2}{*}{ Rank } \\
\hline & KG98 & KATB1 & Navy line 1 & SABRYT & KATB9 & Lyamungu 85 & JESCA & & \\
\hline Good market & 3 & 5 & 4 & 4 & 4 & 5 & 3 & 28 & 1 \\
\hline High yield & 4 & 4 & 4 & 4 & 3 & 4 & 4 & 27 & 2 \\
\hline Drought tolerance & 3 & 3 & 4 & 4 & 3 & 4 & 4 & 25 & 4 \\
\hline Early maturity & 3 & 5 & 3 & 3 & 4 & 3 & 5 & 26 & 3 \\
\hline Tolerance to disease/pest & 3 & 3 & 3 & 3 & 3 & 3 & 4 & 22 & 5 \\
\hline Total & 16 & 20 & 18 & 18 & 17 & 17 & 18 & & \\
\hline Rank & 4 & 1 & 2 & 2 & 3 & 3 & 2 & & \\
\hline
\end{tabular}

Note. $1=$ Poor; $2=$ Satisfactory; $3=$ Average; $4=$ Good; and $5=$ Excellent.

Table 8. Pair wise ranking of bean varieties at Maruku-Kagera

\begin{tabular}{|c|c|c|c|c|c|c|c|c|c|}
\hline & JESCA & Lyamungu 85 & KATB9 & SARBYT & Navy line 1 & KATB1 & KG98 & Total & Rank \\
\hline JESCA & & Lyamungu 85 & JESCA & SARBYT & JESCA & JESCA & JESCA & 4 & 2 \\
\hline Lyamungu 85 & & & KATB9 & Lyamungu 85 & Lyamungu 85 & KATB1 & Lyamungu 85 & 4 & 2 \\
\hline КАТВ9 & & & & KATB9 & Navy line 1 & KATB1 & KATB9 & 3 & 3 \\
\hline SARBYT & & & & & Navy line 1 & KATB1 & SARBYT & 2 & 4 \\
\hline Navy line 1 & & & & & & KATB1 & Navy line 1 & 3 & 3 \\
\hline KATB1 & & & & & & & KATB1 & 5 & 1 \\
\hline KG98 & & & & & & & & $\mathbf{0}$ & 5 \\
\hline
\end{tabular}

Table 9. Matrix ranking bush bean varieties Selian- Arusha

\begin{tabular}{|c|c|c|c|c|c|c|c|c|c|}
\hline \multirow{2}{*}{ Criteria } & \multicolumn{7}{|c|}{ Bean candidates } & \multirow{2}{*}{ Total } & \multirow{2}{*}{ Rank } \\
\hline & KG98 & KATB1 & Navy line 1 & SABRYT & KATB9 & Lyamungu 85 & JESCA & & \\
\hline Grain market quality & 2 & 6 & 4 & 4 & 4 & 5 & 3 & 28 & 1 \\
\hline High yield & 4 & 4 & 4 & 4 & 4 & 3 & 4 & 27 & 2 \\
\hline Drought tolerance & 3 & 3 & 4 & 4 & 3 & 4 & 4 & 25 & 4 \\
\hline Early maturity & 3 & 5 & 3 & 3 & 5 & 2 & 5 & 26 & 3 \\
\hline Tolerance to disease/pest & 3 & 3 & 3 & 3 & 3 & 3 & 4 & 22 & 5 \\
\hline Total & 15 & 21 & 18 & 18 & 17 & 17 & 19 & & \\
\hline Rank & 4 & 1 & 2 & 2 & 3 & 3 & 2 & & \\
\hline
\end{tabular}

Note. 1 = Poor; 2 = Satisfactory; 3 = Average; 4 = Good; and 5 = Excellent. 
Table 10. Pair wise ranking of bean varieties Uyole - Mbeya

\begin{tabular}{|c|c|c|c|c|c|c|c|c|c|}
\hline & JESCA & Lyamungu 85 & KATB9 & SARBYT & Navy line 1 & KATB1 & KG98 & Total & Rank \\
\hline JESCA & & Lyamungu 85 & KATB9 & SARBYT & JESCA & JESCA & JESCA & 4 & 2 \\
\hline Lyamungu 85 & & & KATB9 & Lyamungu 85 & Lyamungu 85 & KATB1 & Lyamungu 85 & 4 & 2 \\
\hline КАТВ9 & & & & KATB9 & Navy line 1 & KATB1 & КАТВ9 & 4 & 2 \\
\hline SARBYT & & & & & SARBYT & KATB1 & SARBYT & 3 & 3 \\
\hline Navy line 1 & & & & & & KATB1 & Navy line 1 & 3 & 3 \\
\hline KATB1 & & & & & & & KATB1 & 5 & 1 \\
\hline KG98 & & & & & & & & $\mathbf{0}$ & 5 \\
\hline
\end{tabular}

Table 11. Absolute Ranking of tested bean varieties

\begin{tabular}{llll}
\hline No & Bush bean varieties & Participants & Rank \\
\hline 1 & KATB 1 & 6 & 1 \\
2 & JESCA & 1 & 5 \\
3 & Lyamungu 85 & 1 & 6 \\
4 & KG 98 & 0 & 7 \\
5 & KATB 9 & 4 & 2 \\
6 & SARBYT & 2 & 4 \\
7 & Navy line 1 & 3 & 3 \\
\hline
\end{tabular}

Some of basic descriptions of the selected bean varieties:

\section{KATB $9=$ SELIAN 12}

Growth habit-Dwarf

Plant height-Medium $(50 \mathrm{~cm})$

Seed shape/size - Round/medium

Seed colour-Red

\section{KATB $1=$ SELIAN 13}

Growth habit-Dwarf

Plant height-Medium $(40 \mathrm{~cm})$

Seed shape/size-Round/medium

Yellow

Integrating conventional assessment for disease tolerant/resistance, drought tolerance, adaptation to low fertility soils, early maturity and high yield shortenstime and increases efficiency in crop breeding program and quick adoption process by bringing the selection process much closer to the farmers in collaboration with researchers and extension officers. On the strength of the attributes and evidence from field and farmers assessments, the Phaseolus bean research programme together with Tanzania Official Seed Certification Institute (TOSCI) and National Variety Release Committee (NVRC) officiated the releases of these new bean varieties and named KATB 9 as SELIAN 12 and KATB1 as SELIAN 13 (Seed Act, 2003; Seed Regulation, 2017). The selected varieties will help in complementary of the existing bean seed availability gap and increased diversity of farmer demanded variety (ies) options. Consequently, improved flexibility on seed access to stakeholders', especially smallholder farmers and commercial growers for seed supply systems for enhanced food security and incomes to end users.

\section{Acknowledgements}

We acknowledge the productive partnerships within our PABRA and ECABREN. We also express deep gratitude to the Government of Tanzania, our donors especially Bill and Melinda Gates Foundation through TropicalLegumes III Project 2015-2019 with contract ID No. OPP1114827 undertaken by CGIAR \& NARS partners. The Swiss Development Cooperation Agency, the Global Affairs Canada Development Agency and the United States Agency for International Development.

\section{References}

Bidinger, F. R. (1998). Farmer participation in pearl millet research in Namibia (pp. 21-30). Proceedings of Participatory Plant Improvement. MS Swaminathan Research Foundation-International Crops Research Institute for the Semi-Arid Tropics workshop. Chennai, India: MS Swaminathan Research Foundation.

Binagwa, P. H. (2016). State of the Art: National Report: Phaseolus Bean Research Programme. Selian Agricultural Research Institute Arusha, Tanzania. 
Bishaw, Z., \& Turner, M. (2008). Linking participatory plant breeding to the seed supply system. Euphytica, 163(1), 31-44.

Buruchara, R., Mukankusi, C., \& Ampofo, K. (2010). Bean Disease and Pests Identification Management. Handbooks for small-scale seed producer. Kampala, Uganda.

Ceccarelli, S., Grando, S., \& Booth, R. H. (1996). International breeding programmes and resource-poor farmers: Crop improvement in difficult environments. In P. Eyzaguirre, \& M. Iwanaga (Eds.), Participatory plant breeding (pp. 99-116). Proceeding of a workshop on participatory plant breeding, 26-29 July 1995, Wageningen, The Netherlands. IPGRI, Italy.

Ceccarelli, S., Grando, S., Baum, M., \& Udupa, S. M. (2004). Breeding for Drought Resistance in a Changing Climate (pp. 167-190).

CIAT (Centro Internacional de Agricultura Tropical). (1987). Standard system for the evaluation of bean germplasm (p. 54). Cali, Colombia.

CIAT (Centro Internacional de Agricultura Tropical). (2003). Increasing Food Security and Rural Incomes in Eastern, Central and Southern Africa through Genetic Improvement of Bush and Climbing Beans. Summary Project Results and Achievements 2001-2003.

FAO (Food Agricultural Organization). (2013). FAOSTAT database. Retrieved from http:/faostat.fao.org

FAO (Food Agricultural Organization). (2015). The state of food and agriculture. Social protection and agriculture. Breaking the cycle of rural poverty. FAO Statistical development series, Rome Italy.

FAOSTAT. (2012). FAOSTAT Database. Retrieved from http://faostat.fao.org

FAOSTAT. (2014). Food and Agriculture Organization (of the United Nations), Statistics Division. Retrieved from http://faostat3.fao.org

Gastelo, M. B., Roncal, E. R., \& Landeo, J. (1991). Canchán-INIAA, una nueva variedad de papa para el Perú con resistencia de campo al tizón tardío (p. 69). Lima, Perú.

Gibbs, A. (1997). Focus groups. Social Research Update.

Grisley, W. (1991). Proceedings of workshop on national research planning for bean production in Uganda. Kampala, Uganda.

Kalyebara, M. R., Andima, D., Roger, K., \& Robin, B. (2008). Improved Bean Varieties and Cultivation Practices in Eastern-Central Africa: Economic and Social Benefits. Centro Internacional de Agricultura Tropical, Cali, Colombia.

Katungi, E., Farrow, A., Chianu, J., Sperling, L., \& Beebe, S. (2009). Common bean in Eastern and Southern Africa: a situation and outlook analysis. International Centre for Tropical Agriculture.

Kundy, A. C., Mponda, O., \& Mkandawile, C. (2015b). Participatory Variety Selection: Farmers Participation In Pigeon Pea (Cajanus cajan L., Millisp.) Varieties Selection in Southern Tanzania. Research Journal of Agriculture, 2, 1-9.

Kundy, A. C., Mponda, O., Mkandawile, C., \& Mkamilo, G. (2015a). Yield evaluation of eighteen pigeon pea (Cajanus cajan (L.) Millsp.) Varieties in south eastern Tanzania. European Journal of Physical and Agricultural Sciences, 3(2), 9-15.

Letaa, E., Kabungo, C, Katungi, E., Ojara, M., \& Nduguru, A. (2015). Farm level adoption and sp a tial diffusion of improved common bean varieties in southern highlands of Tanzania. African Crop Science Journal, 23(3), 261-277.

Mishili, F. J., Temu, A. A., Fulton, J., \& Lowenberg-DeBoer, J. (2009). Consumer preferences as drivers of the common bean trade in Tanzania: A marketing perspective. Journal of International Food \& Agribusiness Marketing, 23, 09-02.

National Bureau of Statistics. (2008). Tanzania Agriculture Sample Census of Agriculture Small-holder Survey.

Nile, B. (2012). Estimating the Impact of Climate Change on Agriculture in Low-Income Countries (p. 52). Environ Resource Econ.

PABRA (Pan-Africa Bean Research Alliance). (2009). Annual Report 2007-2008. Kampala, Uganda.

Rugambisa, J. (1990). Marketing of beans in Sub- Saharan Africa and impact of market on new cultivars. In J. B. Smithson (Ed.), Progress in improvement of common bean in Eastern and Southern Africa. Proceedings of 
the Ninth SUA/CRSP and Second SADCC/CIAT Bean Research Workshop, Sokoine University of Agriculture, Morogoro, Tanzania, 17-22 September, 1990. CIAT Africa Workshop Series No. 12.

Salami, A., Kamara, A. B., \& Brixiova, Z. (2010). Smallholder Agriculture in East Africa: Trends, Constraints and Opportunities. Working Papers Series No. 105. African Development Bank, Tunis, Tunisia.

Sankaran, S., Carter, A., Helmut, K., Slaughter, D., Okamuro, J., Poland, J., \& Kalcsits, L. (2015). Advances in Field-Based High-throughput Phenotyping and Data Management. Grains and Specialty Crops. Summary Progress Report presented Red Lion Hotel at Washington DC on November 9, 2015.

Stewart, D. W., Shamdasani, P. N., \& Rook, D. W. (2007). Focus Groups: Theory and Practice (2nd ed.). Thousand Oaks, CA: Sage. https://doi.org/10.4135/9781412991841

Texas A\&M Agrilife Extension. (n.d.). Texas plant disease handbook. Retrieved from https://plantdiseasehand book.tamu.edu/problems-treatments/problems-affecting-multiple-crops/drought-symptoms-on-plants

The Country STAT. (2013). Statistic Unit-National Secretariat. Ministry of Agriculture, Livestock and Fisheries.

The Seed Act. (2003). The United Republic of Tanzania Seed. Retrieved from http://www.kilimo.go.tz

The Seed Regulation. (2017). The United Republic of Tanzania Seed. Retrieved from http://www.kilimo.go.tz

Tripp, R. (1997). New Seed and Old Laws. Regulatory reform and the diversification of national seed systems (p. 259). London: Overseas Development Institute. https://doi.org/10.3362/9781780445588

Weltzien, E., Smith, M. E., Meitzner, L. S., \& Sperling, L. (2003). Technical and institutional issues in participatory plant breeding-from the perspective of formal plant breeding: A global analysis of issues, results, and current experience (p. 226, PPB Monograph No. 1). Cali, Colombia: PRGA Program.

Witcombe, J. R., \& Virk, D. S. (1997). New directions for public sector variety testing. In R. Tripp (Ed.), New Seed and Old Laws. Regulatory reform and the diversification of national seed systems (pp. 59-87). ITP on Behalf of Overseas Development Institute. https://doi.org/10.3362/9781780445588.004

Witcombe, J. R., Joshi, A., Joshi, K. D., \& Sthapit, B. R. (n.d.). Farmer participatory crop improvement. I: varietal Selection and breeding methods and their impact on Biodiversity. Experimental Agriculture.

Wortmann, C. S., \& Allen, D. J. (1994). African bean production environments. Their definition, characteristics, and constraints. Network on Bean Research in Africa, Dar es Salaam, Tanzania. Occasional Publication Series, 11, 45-51.

\section{Copyrights}

Copyright for this article is retained by the author(s), with first publication rights granted to the journal.

This is an open-access article distributed under the terms and conditions of the Creative Commons Attribution license (http://creativecommons.org/licenses/by/4.0/). 